\title{
MIR204 Gene
}

National Cancer Institute

\section{Source}

National Cancer Institute. MIR204 Gene. NCI Thesaurus. Code C81789.

This gene is involved in the regulation of gene expression and plays a role in the development of breast carcinoma, cholangiocarcinoma and acute myeloid leukemia. 